\title{
食品の機能性研究最前線：老化とストレス
}

\author{
高 橋 良 哉, ${ }^{*}, a$ 海野けい子 $b$
}

\section{Recent Advances in the Functionality of Foods: Aging and Stress}

\author{
Ryoya Takahashi*,a and Keiko Unno ${ }^{b}$ \\ ${ }^{a}$ Department of Biochemistry, Faculty of Pharmaceutical Sciences, Toho University; 2-2-1 Miyama, Funabashi, Chiba \\ 274-8510, Japan: and ${ }^{b}$ Department of Neurophysiology, School of Pharmaceutical Sciences, \\ University of Shizuoka; 52-1 Yada, Suruga-ku, Shizuoka 422-8526, Japan.
}

野菜, 果物, 豆類, 芋類, 海藻, お茶などのほと んどの植物性食品に含まれる色素や香り, 苦味成分 などの非栄養素に生理活性があることが, 近年, 次々に明らかにされている。これらの化学物質は ファイトケミカル (phytochemical) とよばれ，抗 酸化能を有するものが多く，その生理活性は多様で ある. ファイトケミカルは, ポリフェノール類, 含 硫化合物, カロテノイド類などに分類される. ポリ フェノール類には強い抗酸化作用があり, 代謝促 進, 免疫賦活, 脳機能賦活などの生理活性があるこ とが知られている，一方，含硫化合物は，ブロッコ リー，にんにくなどに含まれる成分であり，抗酸化 作用や抗菌作用のほか，がん抑制効果が期待されて いる，今日では，ファイトケミカルは，「第 7 の栄 養素」ともよばれ，他の栄養素とともに健康維持・ 増進, 各種疾病に対する予防効果が期待されてお り, 栄養学のみならず医学, 薬学などの分野でも高 い関心を集めている.

日本薬学会第 134 年会の本シンポジウムでは, 「食品の機能性研究最前線 : 老化とストレス」と題 し，ファイトケミカルやそれを含む食品の機能に関 する分子生物学的研究から疫学調查に至るまで, 幅 広い分野の専門家を集め，それぞれの研究分野にお ける最新の研究と将来展望についてご講演頂いた.

本シンポジウムでは, はじめに, オーガナイザー の高橋良哉（東邦大薬）から「老化とストレスに関

$a$ 東邦大学薬学部生化学教室（T274-8510 千葉県船橋 市三山 2-2-1), $b$ 静岡県立大学薬学部統合生理学分野 (干422-8526 静岡市駿河区谷田 52-1)

*e-mail: takahasi@ phar.toho-u.ac.jp

日本薬学会第 134 年会シンポジウム S34 序文
する食品の機能性研究の現状」として, レスベラト ロールとクルクミンの研究をとり上げ, 両ファイト ケミカルの実験動物に対する寿命延長効果に最近, 疑問が投げかけ始められていることを紹介した。こ れらの内容については, 講演で紹介できなかった ファイトケミカルを含め, 誌上シンポジウムとして 本誌にまとめた.

海野けい子先生（静岡県大薬）には，「食品成分 による老化及びストレスの予防」と題して, 緑茶力 テキンと温州ミカンの $\beta$-クリプトキサンチンの脳 老化抑制作用について老化促進モデルマウス （SAMP10）を用いた研究成果を紹介して頂いた.

さらに, マウスへの社会心理的ストレスの長期負荷 による脳機能低下と寿命短縮に対するテアニン（緑 茶に含まれるアミノ酸の一種）の抑制効果について 紹介して頂いた。 これらの講演内容は, 多くのデー タとともに誌上シンポジウムとしてまとめて頂いた.

村上 明先生 (京都大院農) には, シンポジウム では「プロテオホルミシスを介した食品成分の生理 機能性発現機構」と題して, 食品成分あるいは天然 化合物の作用機構, 生理機能の評価の問題について お話し頂いた. 誌上シンポジウムでは, 講演でもと り上げたセスキテルペンの一種である zerumbone の標的分子探索過程で明らかになつた特異的及び非 特異的な作用機構の寄与について「生体タンパク質 との非特異的な相互作用を介した食品成分の機能性 発現機構」と題してまとめて頂いた.

次に, 都築 毅先生（東北大院農）には「日本食 は脳機能の老化を遅延できる!?」と題して, 高度 経済成長からバブル崩壊後までの年代別日本食の健 康有益性について講演して頂いた。 日本食の効果を 
DNA マイクロアレイ解析による遺伝子発現レベル で評価した動物実験などを紹介して頂いた。誌上シ ンポジムでは, 日本食の有益性, 日本食の特徵とも なっている魚油の長期摂取が寿命に与える影響につ いて講演内容を含め詳しくまとめて頂いた.

最後に杉浦 実先生（農研機構果樹研）に「 $\beta$-ク リプトキサンチンと生活習慣病予防」についての膨 大な疫学調査の研究成果を紹介して頂いた. 誌上シ ンポジウムでは, $\beta$-クリプトキサンチンと動脈硬化 や肝疾患, メタボリックシンドロームなどの様々な
生活習慣病リスクとの負の関係について最近の疫学 研究の知見を入れて紹介して頂いた。

本シンポジウム及び本誌上シンポジウムでは, 食 品の機能に関する分子生物学的研究から疫学的調査 に至る様々な分野における最新の研究成果をとり上 げた，本企画が本学会の研究者，教育者，医療関係 者のみならず，将来薬剤師として医療機関あるいは 企業・研究機関等において医薬品開発に携わる学生 にとっても役立つことを期待する. 